\title{
The Ammonia and Methylamine Active Transport System of Aspergillus nidulans
}

\author{
By ROBERT J. COOK* AND CHRISTOPHER ANTHONY \\ Department of Biochemistry, School of Biochemical and Physiological Sciences, \\ University of Southampton, Southampton SO9 $3 T U$
}

(Received 5 May 1978)

Conidia of Aspergillus nidulans germinated on glutamate have a single system for the active transport of ammonia and methylamine against a concentration gradient. The transport of methylamine is inhibited by azide, $\mathrm{N}$-ethylmaleimide, valinomycin and anaerobiosis; it has a pH optimum of about 6.3 and a temperature optimum of $40^{\circ} \mathrm{C}$. The affinity of the system for methylamine $\left(K_{\mathrm{m}} 13 \mu \mathrm{M}\right)$ is about $20 \%$ of that for ammonia; the $V_{\max }$ is also much lower. This transport system is present in methylamine-resistant mutants (mea $A$ and $m e a B$ loci) and its formation is repressed in wild type and mutants by ammonia or a metabolite of ammonia. It is proposed that the system functions in the scavenging of low concentrations of ammonia during nitrogen starvation or during growth on other major nitrogen sources.

\section{INTRODUCTION}

In Aspergillus nidulans, as in other microfungi, ammonia plays a key role in the regulation of nitrogen metabolism (Arst \& Cove, 1969; Pateman et al., 1973; Robinson, 1973; Cook, 1976). Ammonia is used preferentially by this organism when presented with mixtures of nitrogen sources (Robinson et al., 1974) and the mechanism of the preferential utilization of ammonia rather than glutamate has been shown to be due to regulation of the acidic amino acid transport system by ammonia or a metabolite of ammonia (Robinson et al., $1973 a, b)$. By contrast, relatively little is known about the system for transport of ammonia itself or the regulation of such a system. Hackette et al. (1970) have characterized an ammonia transport system in Penicillium chrysogenum using the ammonia analogue $\left[{ }^{14} \mathrm{C}\right]$ methylamine as the substrate and their preliminary results indicated that $P$. notatum and $A$. nidulans were also able to transport methylamine.

The present paper describes an ammonia transport system in A. nidulans and demonstrates that ammonia and methylamine are transported by the same system. A preliminary report of some of these results has been published (Cook \& Anthony, 1973) and some similar results have been obtained in a study of mutants with altered transport systems (Pateman et al., 1974). The detailed characterization in the present paper is an essential basis for the investigation of regulation of ammonia transport described in the following paper (Cook \& Anthony, 1978).

\section{METHODS}

Chemicals. All chemicals were reagent grade and almost all were obtained from BDH. The exceptions were: valinomycin (A grade) from Calbiochem; butyl-PBD [2-(4'-tert-butylphenyl)-5-(4"-biphenylyl)1,3,4-oxadiazole] from Koch-Light; agar no. 3 (L13) and malt extract (L39) from Oxoid; L-[U-14C]glutamate $\left(14.7 \mathrm{mCi} \mathrm{mmol}^{-1}\right)$ and $\left[{ }^{14} \mathrm{C}\right]$ methylamine hydrochloride $\left(56 \mathrm{mCi} \mathrm{mmol}^{-1}\right)$ from The Radiochemical Centre,

* Present address: Biochemistry Department, Vanderbilt University School of Medicine, Nașhille, Tennessee 37323, U.S.A. 
Amersham; $\beta$-nicotinamide-adenine dinuleotide (reduced form) and L-glutamate dehydrogenase(bovineliver, type II) from Sigma.

Organism and growth media. A translocation-free, biotin-requiring strain (biAl) (Pontecorvo et al., 1953) of Aspergillus nidulans was used in this work. The organism and methylamine-resistant derivative mutants were kindly supplied by Dr H. N. Arst and Dr D. J. Cove, Department of Genetics, University of Cambridge. The mutants are described by Arst \& Cove $(1969,1973)$ and Arst \& Page $(1973)$. Stock cultures were maintained on slopes of malt extract $(3 \%, w / v)$ solidified with Oxoid agar no. $3(1.5 \%, w / v)$. The growth media have been described previously (Robinson et al., 1973a).

Germination of conidia in aerated liquid cultures. Conidial suspensions (approx. $10^{7} \mathrm{ml}^{-1}$ ) were prepared and germinated as described previously (Robinson et al., 1973a). Unless otherwise stated, the conidia were germinated until germ tubes were just visible in more than $80 \%$ of the conidia (usually 10 to $12 \mathrm{~h}$ after inoculation).

Measurement of transport of ${ }^{14} \mathrm{C}$-labelled compounds. This was measured at $30^{\circ} \mathrm{C}$ immediately after harvesting; the method is fully described elsewhere (Robinson et al., 1973a).

Determination of radioactivity. Samples of mycelium, conidia or germinated conidia, on Whatman no. 1 paper discs (13 mm diam.), were placed in glass scintillation vials with $10 \mathrm{ml}$ scintillation fluid $[8 \mathrm{~g}$ butyl-

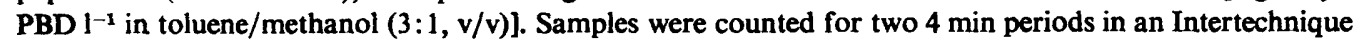
ABAC SL40 liquid scintillation counter. In samples with low radioactivity, the counting period was extended to 10 or $20 \mathrm{~min}$. In all cases of low radioactivity, the background radioactivity of the vial was determined prior to addition of the sample. Under the conditions used, quenching of the radioactivity was approximately equal in every sample, and never exceeded $10 \%$ of the total radioactivity. The same procedure was used to determine radioactivity in aqueous samples, a volume not exceeding $0.1 \mathrm{ml}$ being added to the scintillant.

Measurement of ammonia transport. The transport of ammonia by germinated conidia of $A$. nidulans was measured by following the decrease in ammonia concentration in the uptake medium. Ammonia was assayed enzymically using L-glutamate dehydrogenase, 2-oxoglutarate and NADH (Cooney et al., 1971).

Extraction and chromatography of intracellular amino acids and related compounds. These extractions were done at pH 6.0 as described previously (Robinson et al., 1973a). The intracellular concentration of extracted compounds was calculated by assuming that the intracellular volume of germinated conidia was three times their dry weight (Pall, 1970; Robinson et al., 1973b).

Radioactive components of the extracts of germinated conidia were separated by ion exchange chromatography using a method based on that of Suzuki (1973). The extract (1.5 ml) was applied to a column (120x $6 \mathrm{~mm}$ ) of Dowex 50W-X8 ( $\mathrm{Na}^{+}$form). The sample was washed on to the column with $6 \mathrm{ml}$ distilled water. Fractions $(1 \mathrm{ml})$ were collected from the column and $50 \mu 1$ of each fraction was used to determine the radioactivity. Adsorbed compounds were eluted with sodium chloride $(1.0 \mathrm{M})$. Fractions $(1 \mathrm{ml})$ were collected until at least $95 \%$ of the radioactivity applied to the column had been eluted. This process removed methylamine, other amines and basic amino acids from the extract and allowed all other compounds to be eluted by the addition of distilled water. The radioactive material in the distilled water eluate (from the previous stage) was pooled and applied to a column $(300 \mathrm{~mm} \times 10 \mathrm{~mm})$ of Amberlite IR-120 (H+-form). The sample was washed on to the column with distilled water, $1 \mathrm{ml}$ eluate fractions were collected and $50 \mu 1$ of each fraction was counted to determine the radioactivity. The eluate contained organic acids and sugars. The column was further eluted with ammonia $(2 \mathrm{M})$ until all the radioactivity was removed. This eluate contained neutral and acidic amino acids.

[14C]Methylamine of known specific activity was chromatographed in an identical way to that described above to confirm the identity of the major labelled peak.

Assay of methylamine. Methylamine was estimated by the method of Large et al. (1969) which utilizes methylamine dehydrogenase coupled to 2,6-dichlorophenolindophenol in the presence of phenazine methosulphate.

\section{RESULTS}

Robinson et al. $(1973 a, b)$ have shown that amino acids are transported at very low rates in conidia and that these rates increase markedly during germination, the highest specific activities being measured just after the first observable emergence of germ tubes. Preliminary results indicated that the maximum activity of the ammonia and methylamine transport system also occurs at the time of germ tube emergence. Conidia were therefore germinated to this stage of development for characterization of the ammonia and methylamine transport system. 

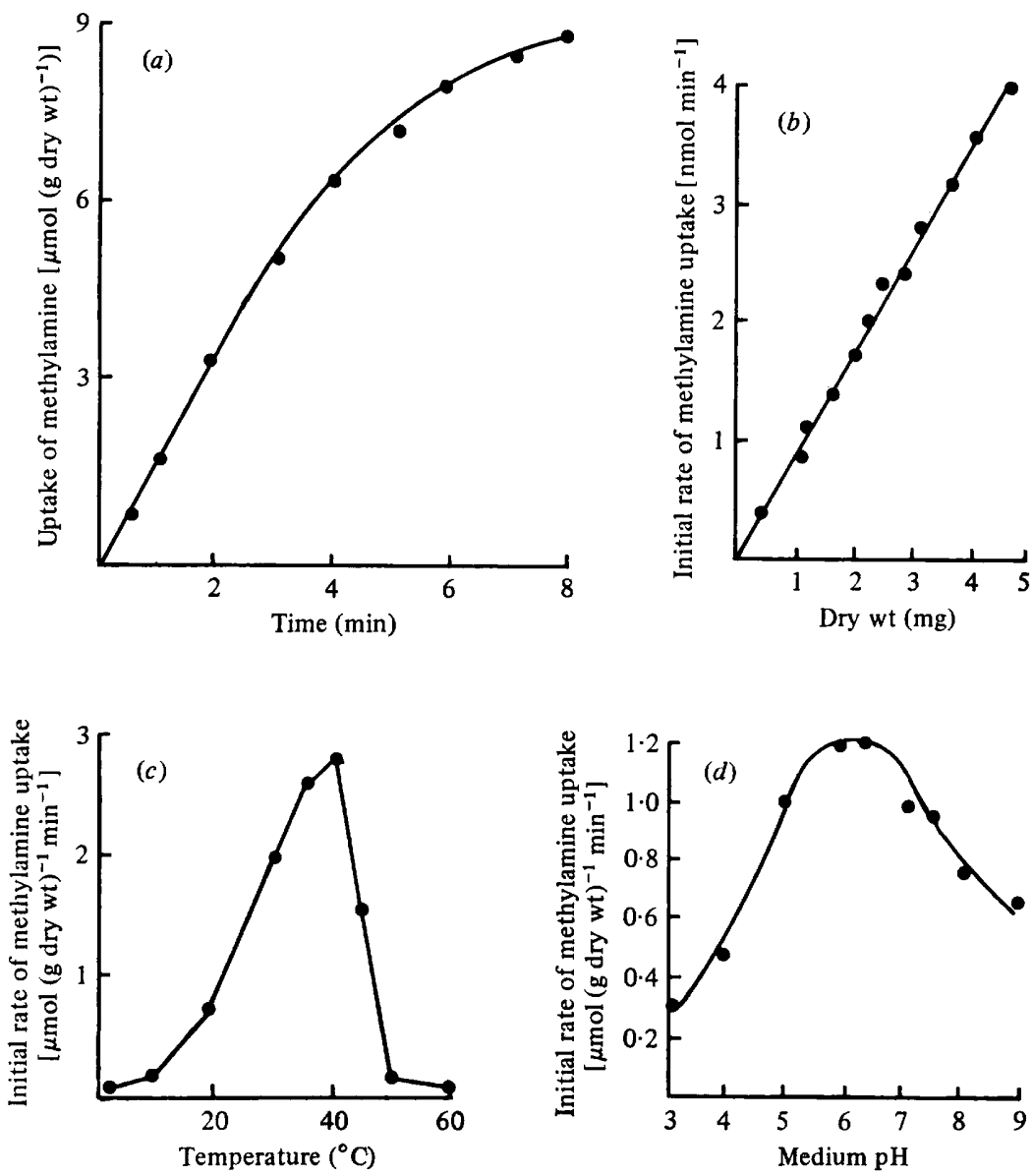

Fig. 1. Kinetics of methylamine transport by germinated conidia of $A$. nidulans. Conidia were germinated for $10 \mathrm{~h}$ at $30^{\circ} \mathrm{C}$ in a glutamate $(25 \mathrm{~mm})$ medium and transport of $\left[{ }^{14} \mathrm{C}\right]$ methylamine $(20 \mu \mathrm{M})$ was measured as described in Methods. (a) Time course of methylamine transport. (b) Rate of methylamine transport as a function of mass of germinated conidia. (c) Rate of methylamine transport as a function of temperature. $(d)$ Rate of methylamine transport as a function of the $\mathrm{pH}$ value of the assay medium. The $\mathrm{Na}^{+} / \mathrm{K}^{+}$phosphate buffer in the transport assay medium was replaced with a buffer made up of citric acid $(0 \cdot 1 \mathrm{M}), \mathrm{Na}^{+} / \mathrm{K}^{+}$phosphate $(0 \cdot 2 \mathrm{M})$ and Tris $(0 \cdot 2 \mathrm{M})$. This mixture was adjusted to the required $\mathrm{pH}$ by adding $\mathrm{HCl}(0 \cdot 1 \mathrm{M})$ or $\mathrm{NaOH}(0 \cdot 1 \mathrm{M})$.

\section{Assay system for measurement of methylamine transport}

The time course of methylamine $(20 \mu \mathrm{M})$ transport by germinated conidia of $A$. nidulans was approximately linear over the first 3 min of assay (Fig. $1 a$ ) and this initial period was used to calculate the initial rate of methylamine transport in all subsequent experiments. Washing of the conidia removed some extracellularly-bound $\left[{ }^{14} \mathrm{C}\right]$ methylamine but the measured rate of methylamine transport was the same when measured after washing with one or two $10 \mathrm{ml}$ volumes of distilled water (at 2 or $30^{\circ} \mathrm{C}$ ) or transport medium (at 2 or $\left.30^{\circ} \mathrm{C}\right)$.

The results in Fig. $1(b)$ show that the rate of transport of $\left[{ }^{14} \mathrm{C}\right]$ methylamine by germinated conidia was directly proportional to the dry weight over the entire range used in this work $(0.25$ to $2.0 \mathrm{mg}$ dry wt per $0.5 \mathrm{ml} \mathrm{sample})$.

The high temperature optimum of $40^{\circ} \mathrm{C}$ for methylamine transport (Fig. 1c) is the same as the temperature optimum for growth of $A$. nidulans (Pontecorvo et al., 1953). The rate of 


\section{Table 1. Uptake of $\left[{ }^{14} \mathrm{C}\right]$ methylamine against a concentration gradient}

Conidia were germinated for approx. $10 \mathrm{~h}$ with glutamate $(25 \mathrm{~mm})$ as the sole nitrogen source. The germinated conidia were washed and loaded with methylamine by incubation for $1 \mathrm{~h}$ in growth medium containing either 2.5 or $25 \mathrm{~mm}$-methylamine. After washing, the transport of methylamine (initial concentration $20 \mu \mathrm{M}$ ) was measured as described in Methods. The intracellular concentration of methylamine was determined by extracting germinated conidia with boiling water followed by enzymic analysis using methylamine dehydrogenase (for experimental details, see Methods).

\begin{tabular}{|c|c|c|}
\hline Incubation medium & $\begin{array}{l}\text { Methylamine } \\
\text { transport* }\end{array}$ & $\begin{array}{l}\text { Intracellular } \\
\text { methylamine } \\
\text { concn (mM) }\end{array}$ \\
\hline $\begin{array}{l}\text { No methylamine } \\
\text { Methylamine }(2.5 \mathrm{~mm}) \\
\text { Methylamine }(25 \mathrm{~mm})\end{array}$ & $\begin{array}{l}1.78 \\
0.75 \\
0.52\end{array}$ & $\begin{array}{r}0 \\
117 \\
105\end{array}$ \\
\hline
\end{tabular}

methylamine transport varied with the $\mathrm{pH}$ value of the assay medium (Fig. $1 d$ ) and showed an optimum between $\mathrm{pH} 6.0$ and 6.5 ; this is similar to that for methylamine transport in $P$. chrysogenum (Hackette et al., 1970). It should be noted that at the $\mathrm{pH}$ values used in the present work ammonia and methylamine are both in the protonated form.

\section{Transport of $\left[{ }^{14} \mathrm{C}\right]$ methylamine against a concentration gradient}

Methylamine is not normally present in $A$. nidulans and so the uptake of methylamine is not initially against a concentration gradient. To demonstrate that methylamine transport may occur against a concentration gradient, germinated conidia were incubated in media containing either 2.5 or $25 \mathrm{~mm}$-methylamine as the sole nitrogen source for $1 \mathrm{~h}$ and then the rate of methylamine transport and intracellular concentration of methylamine were measured (Table 1). The results show that in the presence of a high intracellular concentration of methylamine the conidia were still able to transport $\left[{ }^{14} \mathrm{C}\right]$ methylamine $(20 \mu \mathrm{M})$ at a high rate. It can be concluded that transport of methylamine does occur against a concentration gradient of at least 1:5000 when germinated conidia are pre-loaded with methylamine.

\section{Metabolism of $\left[{ }^{14} \mathrm{C}\right]$ methylamine during the transport assay period}

If methylamine was oxidized by an amine oxidase after transport into germinated conidia, a lower rate of methylamine uptake would be measured, because some radioactivity would be lost as ${ }^{14} \mathrm{CO}_{2}$. The oxidation of $\left[{ }^{14} \mathrm{C}\right]$ methylamine to ${ }^{14} \mathrm{CO}_{2}$ by conidia was therefore measured using the method of Ressler \& Koga (1971). Of the $\left[{ }^{14} \mathrm{C}\right]$ methylamine transported in 10 min [ 97000 c.p.m. (mg dry wt) $)^{-1}$ ] only $0.23 \%$ was recovered as ${ }^{14} \mathrm{CO}_{2}$ showing that the oxidation of transported methylamine to $\mathrm{CO}_{2}$ was minimal and had no significant effect on the measurement of the rate of $\left[{ }^{14} \mathrm{C}\right]$ methylamine transport.

The metabolism of $\left[{ }^{14} \mathrm{C}\right]$ methylamine was also investigated using the modified technique of Suzuki (1973, see Methods). Germinated conidia were incubated with $\left[{ }^{14} \mathrm{C}\right]$ methylamine $\left[20 \mu \mathrm{M} ; 0.25 \mu \mathrm{Ci}(40 \mathrm{nmol})^{-1}\right]$ for $13 \mathrm{~min}$. Analysis of the intracellular radioactive compounds showed that $84 \%$ of the radioactivity was still in $\left[{ }^{14} \mathrm{C}\right]$ methylamine; the remaining $16 \%$ of the radioactivity was associated mainly with neutral and acidic amino acids $(12.5 \%)$. Organic acids and sugars contained $2 \%$ of the radioactivity and $1.5 \%$ of the counts were lost.

\section{Inhibition of methylamine transport by azide, $N$-ethylmaleimide, valinomycin and anaerobiosis}

Transport of methylamine $(20 \mu \mathrm{M})$ by germinated conidia was almost completely prevented by inhibitors of energy-yielding reactions. After pre-incubation for $90 \mathrm{~s}$ with sodium azide $(10 \mathrm{~mm}), N$-ethylmaleimide $(1 \mathrm{mM})$ or valinomycin $\left(1 \mu \mathrm{g} \mathrm{ml}^{-1}\right)$, the initial rate of methylamine transport was inhibited by more than $90 \%$. Resuspension of germinated 


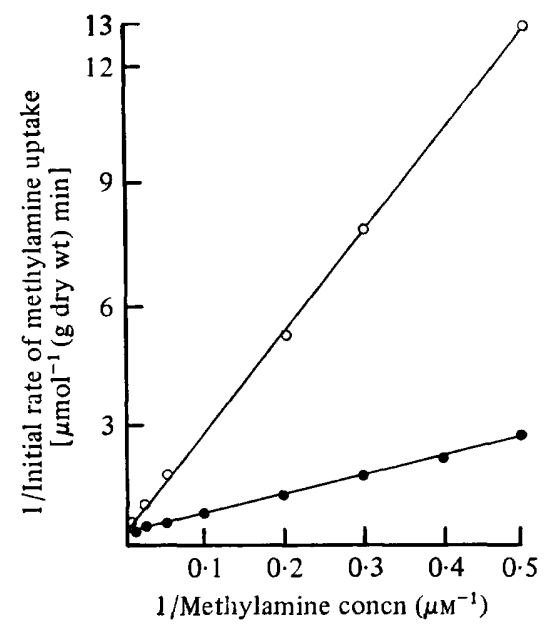

Fig. 2. Kinetics of methylamine transport by germinated conidia of $\boldsymbol{A}$. nidulans and competitive inhibition of methylamine transport by ethylamine. Transport of $\left[{ }^{14} \mathrm{C}\right]$ methylamine was measured with various concentrations of methylamine in the presence or absence of ethylamine $(0.2 \mathrm{~mm})$. Experimental details were as given in Fig. 1. - , Methylamine only; $O$, methylamine with ethylamine.

conidia in an oxygen-depleted medium also led to a $95 \%$ decrease in the rate of methylamine transport.

Kinetics and specificity of the methylamine transport system

The variation of the initial rate of transport of methylamine with the concentration of methylamine in the assay system suggests that only one transport system was operating over the concentration range 2 to $100 \mu \mathrm{M}$ (Fig. 2). The apparent $K_{\mathrm{m}}$ value was $13 \mu \mathrm{M}$ and the $V_{\max }$ was $4 \mu \mathrm{mol}\left(\mathrm{g}\right.$ dry wt) ${ }^{-1} \mathrm{~min}^{-1}$. This $K_{\mathrm{m}}$ value, measured in glutamate-germinated conidia, is similar to that measured in nitrogen-starved cells of $P$. chrysogenum (Hackette et al., 1970) and of $A$. nidulans (Pateman et al., 1974). It is also similar to $K_{\mathrm{m}}$ values for other transport systems, especially those for amino acids, in this organism and in other fungi (for reviews, see Robinson, 1973; Cook, 1976).

Potential substrates of the methylamine transport system were tested for their ability to inhibit methylamine transport (Table 2). Ammonia was the only compound inhibiting at low concentrations. The extent of the inhibition $(65 \%$ when present at the same concentration as methylamine) indicates that the methylamine transport system has a greater affinity for ammonia than for methylamine and that its physiological function may be the transport of ammonia. The relatively slight inhibition by the closely related amines suggests that the prime function of the methylamine transport system is not the transport of higher aliphatic amines or amino alcohols. Of the various amino acids and simple nitrogen compounds tested, only L-asparagine, L-glutamine and L-lysine inhibited transport to any extent; this inhibition may have been due to direct competition at the binding site or to indirect inhibition (see Cook \& Anthony, 1978).

The inhibition of methylamine transport by its structural analogue ethylamine was competitive (Fig. 2); the $K_{\mathrm{i}}$ for ethylamine was $50 \mu$ M. Assuming that this $K_{\mathrm{i}}$ for ethylamine reflects the $K_{\mathrm{m}}$ for its own transport then it appears that the affinity of the methylamine transport system for ethylamine is $20 \%$ of its affinity for methylamine. A similar result was obtained for ethylamine transport in P. chrysogenum (Hackette et al., 1970). 
Table 2. Inhibition of methylamine transport by amines, amino acids and simple nitrogenous compounds

Conidia were germinated for approx. $11 \mathrm{~h}$ at $30^{\circ} \mathrm{C}$ with glutamate $(25 \mathrm{~mm})$ as the sole nitrogen source. After washing, germinated conidia were stirred with the potential inhibitor for approx. $90 \mathrm{~s}$ before addition of $\left[{ }^{14} \mathrm{C}\right]$ methylamine $(20 \mu \mathrm{M})$, with the exception that ammonia $(0.02 \mathrm{~mm})$ was added simultaneously with the labelled substrate. The initial rate of methylamine transport was measured during the first $3 \mathrm{~min}$ of the assay as described in Methods. Results are expressed as percentage inhibition determined by comparing the inhibited initial rate of transport with the initial rate measured in the absence of inhibitor.

\begin{tabular}{|c|c|c|c|c|c|}
\hline $\begin{array}{l}\text { Potential } \\
\text { inhibitor }\end{array}$ & $\begin{array}{l}\text { Concn } \\
(\mathrm{mm})\end{array}$ & $\begin{array}{c}\text { Inhibition } \\
(\%)\end{array}$ & $\begin{array}{l}\text { Potential } \\
\text { inhibitor }\end{array}$ & $\begin{array}{l}\text { Concn } \\
(\mathrm{mM})\end{array}$ & $\begin{array}{c}\text { Inhibition } \\
(\%)\end{array}$ \\
\hline Methylamine & $\begin{array}{l}0.2 \\
2.0\end{array}$ & $\begin{array}{l}80^{*} \\
95\end{array}$ & Glycine & 0.2 & 7 \\
\hline \multirow[t]{3}{*}{ Ammonia } & 0.02 & 65 & L-Glutamate & $\begin{array}{l}2 \cdot 0 \\
0 \cdot 2\end{array}$ & $\begin{array}{r}15 \\
3\end{array}$ \\
\hline & $0 \cdot 2$ & 93 & & $2 \cdot 0$ & 30 \\
\hline & $2 \cdot 0$ & 98 & L-Asparagine & 0.2 & 15 \\
\hline \multirow[t]{2}{*}{ Dimethylamine } & $0 \cdot 2$ & 32 & & $2 \cdot 0$ & 47 \\
\hline & $2 \cdot 0$ & 61 & L-Glutamine & $0 \cdot 2$ & 30 \\
\hline \multirow[t]{2}{*}{ Trimethylamine } & $0 \cdot 2$ & 33 & & $2 \cdot 0$ & 73 \\
\hline & $2 \cdot 0$ & 77 & L-Lysine & $0 \cdot 2$ & 30 \\
\hline \multirow[t]{2}{*}{ Ethylamine } & $0 \cdot 2$ & 32 & & $2 \cdot 0$ & 50 \\
\hline & $2 \cdot 0$ & 50 & L-Phenylalanine & $0 \cdot 2$ & 9 \\
\hline \multirow[t]{2}{*}{ Diethylamine } & 0.2 & 28 & & $2 \cdot 0$ & 20 \\
\hline & $2 \cdot 0$ & 41 & Nitrate & 0.2 & 3 \\
\hline \multirow[t]{2}{*}{$n$-Butylamine } & 0.2 & 14 & & $2 \cdot 0$ & 0 \\
\hline & $2 \cdot 0$ & 18 & Urea & 0.2 & 7 \\
\hline \multirow[t]{2}{*}{ Hydrazine. $\mathrm{HCl}$} & $0 \cdot 2$ & 31 & & $2 \cdot 0$ & 10 \\
\hline & $2 \cdot 0$ & 77 & Ethanolamine & 0.2 & 18 \\
\hline \multirow[t]{2}{*}{ Methanol } & $0 \cdot 2$ & 0 & & $2 \cdot 0$ & 26 \\
\hline & $2 \cdot 0$ & 0 & Diethanolamine & 0.2 & 0 \\
\hline \multirow[t]{2}{*}{ Formamide } & $0 \cdot 2$ & $\mathbf{0}$ & & $2 \cdot 0$ & 25 \\
\hline & $2 \cdot 0$ & 9 & & & \\
\hline
\end{tabular}

\section{Transport of ammonia by germinated conidia}

Ammonia was the only compound which, at low concentrations, appreciably inhibited methylamine transport. However, the apparently high affinity of the transport system for ammonia made conventional competition experiments technically impossible. The time course of methylamine transport in the presence of various concentrations of ammonia (20 to $200 \mu \mathrm{M}$ ) is shown in Fig. 3. The lag period occurring before methylamine transport was proportional to the concentration of ammonia added to the assay system. This supports the suggestion that the delay before maximum methylamine transport was reached was the time taken for the ammonia to be transported into the conidia. An approximate rate of ammonia transport of $17 \mu \mathrm{mol}(\mathrm{g} \text { dry } \mathrm{wt})^{-1} \mathrm{~min}^{-1}$ was calculated for germinated conidia using this assumption. This estimated rate of ammonia transport is 10 -fold higher than the rate of methylamine transport at the concentration used here $(20 \mu \mathrm{M})$. A similar method was used previously for estimating rates of ammonia transport in P. chrysogenum (Hackette et al., 1970).

Using the initial rates measured in Fig. 3 for methylamine $(20 \mu \mathrm{M})$ transport with 20 and $50 \mu \mathrm{M}$-ammonia, the $K_{1}$ value for ammonia was calculated to be about $2.8 \mu \mathrm{M}$, assuming that the $K_{\mathrm{m}}$ value for methylamine is $13 \mu \mathrm{M}$. The $V_{\max }$ for methylamine transport into the conidia used in this experiment was $2.8 \mu \mathrm{mol}(\mathrm{g} \mathrm{dry} \mathrm{wt})^{-1} \mathrm{~min}^{-1}$. Thus the $V_{\max }$ for ammonia is about six times that for methylamine and the affinity for ammonia (assuming $K_{\mathrm{d}}=K_{\mathrm{m}}=$ $\left.K_{\mathrm{i}}\right)$ is about five times that for methylamine.

Ammonia transport was further investigated by measuring the decrease in ammonia concentration in the medium with time. The results of such an experiment, in which both ammonia and methylamine transport were measured, confirm that the lag period occurring 


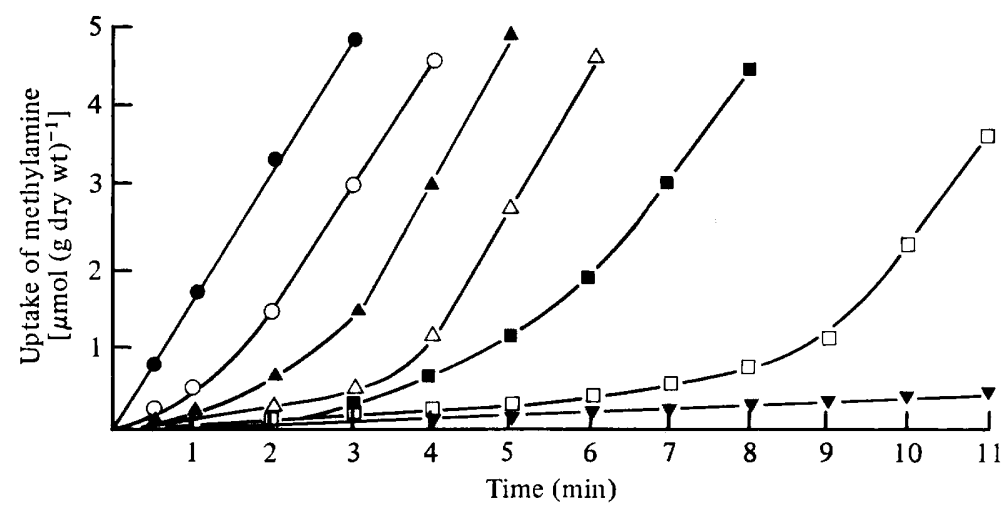

Fig. 3. Inhibition of methylamine transport by ammonia. Transport of $\left[{ }^{14} \mathrm{C}\right]$ methylamine $(20 \mu \mathrm{M})$ was measured in the presence of various concentrations of ammonia. Experimental details were as given in Fig. 1. [ $\left.{ }^{14} \mathrm{C}\right]$ Methylamine and ammonia were added simultaneously at the start of the assay. Ammonia concentrations were $\left(\mu_{\mathrm{M}}\right): \bullet, 0$ (control); $\bigcirc, 20 ; \Delta, 50 ; \triangle, 80 ; \mathbf{\square}, 100 ; \square, 150 ; \nabla, 200$.

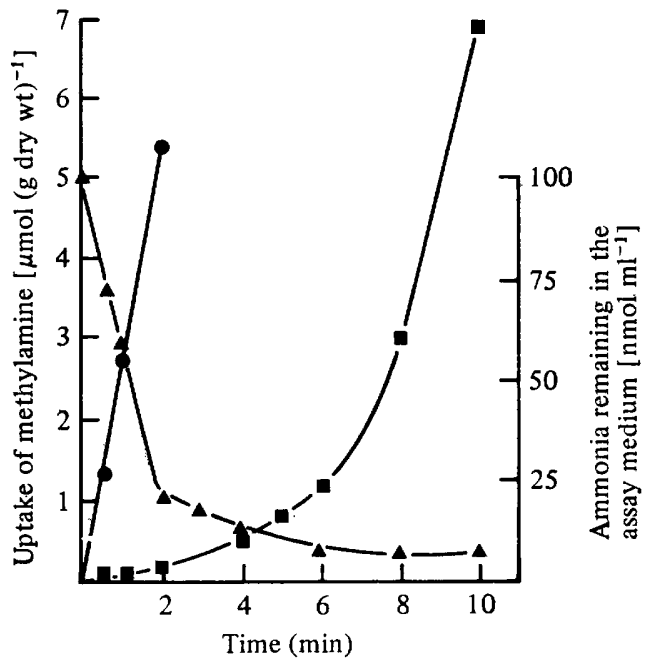

Fig. 4. Transport of methylamine and ammonia by germinated conidia of $A$. nidulans. Experimental details were as given in Fig. 1. Transport of $\left[{ }^{14} \mathrm{C}\right]$ methylamine $(20 \mu \mathrm{M})$ and ammonia $(100 \mu \mathrm{M})$ were measured as described in Methods. $\left[{ }^{14} \mathrm{C}\right]$ Methylamine and ammonia were added simultaneously at the start of the assay. The samples of germinated conidia used to measure methylamine and ammonia transport were washed with $1 \mathrm{ml}$ of cold distilled water. $\bullet$, Methylamine transported into conidia in the absence of ammonia; $\boldsymbol{m}$, methylamine transported into conidia in the presence of ammonia; $\boldsymbol{\Delta}$, ammonia remaining in the assay medium.

before methylamine transport was the time required for ammonia to be removed from the assay medium (Fig. 4). The initial rate of ammonia transport was $28.8 \mu \mathrm{mol}$ (g dry wt) ${ }^{-1}$ $\min ^{-1}$ and this was 10 -fold greater than the rate of methylamine transport. When germinated conidia were incubated at $2{ }^{\circ} \mathrm{C}$, the rates of both ammonia and methylamine transport were negligible; transport occurred at the usual rates when the temperature was raised to $30{ }^{\circ} \mathrm{C}$.

The average intracellular concentration of ammonia in these conidia was $8.6 \mathrm{~mm}$ (Cook, 1976); thus ammonia (initial concentration $100 \mu \mathrm{M}$ ) was transported in these experiments against a concentration gradient of at least $1: 86$. It was impossible to test the sensitivity 


\section{Table 3. Inhibition of ammonia transport by methylamine or ethylamine}

Conidia were germinated for approx. $10 \mathrm{~h}$ at $30^{\circ} \mathrm{C}$ with glutamate $(25 \mathrm{~mm})$ as the sole nitrogen source. The transport of ammonia $(100 \mu \mathrm{M})$ was measured as described in Methods. Methylamine or ethylamine was added simultaneously with ammonia to start the assay. Results are expressed as percentage inhibition determined by comparing the inhibited initial rate of ammonia transport with the initial rate measured in the absence of inhibitor.

\begin{tabular}{|c|c|c|c|}
\hline Inhibitor & $\begin{array}{l}\text { Concn } \\
\text { (mM) }\end{array}$ & $\begin{array}{c}\text { Initial rate of } \\
\text { transport }\end{array}$ & Inhibition (\%) \\
\hline None & 0 & $29 \cdot 3$ & - \\
\hline \multirow[t]{3}{*}{ Methylamine } & 0.1 & $25 \cdot 5$ & 13 \\
\hline & 1.0 & 19.8 & 33 \\
\hline & $10 \cdot 0$ & $9 \cdot 7$ & 67 \\
\hline \multirow[t]{3}{*}{ Ethylamine } & 0.1 & $26 \cdot 4$ & 10 \\
\hline & 1.0 & $24 \cdot 7$ & 16 \\
\hline & $10 \cdot 0$ & $19 \cdot 8$ & 33 \\
\hline
\end{tabular}

Table 4. Methylamine transport in methylamine-resistant mutants of $A$. nidulans germinated with various nitrogen sources

Conidia were germinated at $30^{\circ} \mathrm{C}$ with various nitrogen sources $(25 \mathrm{~mm})$ until germ tubes were visible in at least $90 \%$ of the conidia. The initial rate of $\left[{ }^{14} \mathrm{C}\right]$ methylamine $(20 \mu \mathrm{M})$ transport was measured as described in Methods. Mutation in the mauA gene leads to loss of monoamine oxidase activity (Arst \& Cove, 1969).

Methylamine transport activity $\left[\mu \mathrm{mol}(\mathrm{g} \text { dry } \mathrm{wt})^{-1} \mathrm{~min}^{-1}\right]$ after growth with:

\begin{tabular}{|c|c|c|c|c|}
\hline Strain & Glutamate & Nitrate & Ammonia & $\begin{array}{l}\text { Glutamate } \\
\text { +ammonia }\end{array}$ \\
\hline biAl (wild type) & $1 \cdot 10$ & 0.76 & 0.026 & 0.021 \\
\hline biA1 mauA2 & 0.90 & 0.65 & 0.026 & 0.022 \\
\hline biAl mauA2 meaA 8 & $1 \cdot 55$ & 0.015 & 0.027 & 0.022 \\
\hline biAl mauA2 meaB6 & $2 \cdot 32$ & 0.43 & 0.051 & 0.047 \\
\hline biAl mauA2 meaB20 & $2 \cdot 45$ & 0.43 & 0.034 & 0.033 \\
\hline
\end{tabular}

of the ammonia transport system to metabolic inhibitors because the assay system for ammonia is sensitive to azide, cyanide and $N$-ethylmaleimide.

\section{Inhibition of ammonia transport by methylamine or ethylamine}

Both methylamine and ethylamine inhibited the transport of ammonia (Table 3). This observation supports the concept that there is a single active transport system functioning primarily for the transport of ammonia but which has some affinity, and hence transporting capacity, for methylamine and ethylamine.

\section{Permease activity in conidia germinated with glutamate or ammonia}

Methylamine transport activity in conidia germinated with glutamate $(25 \mathrm{~mm})$ as the sole nitrogen source was high. When conidia were germinated with ammonia $(25 \mathrm{~mm})$ the transport activity was very low (Cook \& Anthony, 1978). If methylamine is transported by an ammonia permease, then the uptake of ammonia would also be expected to be low in ammonia-germinated conidia. This was confirmed by measuring the uptake of ammonia $(0.1 \mathrm{~mm})$ in conidia germinated either with glutamate $(25 \mathrm{~mm})$ or ammonia $(25 \mathrm{~mm})$. The initial rate of ammonia uptake was 60 -fold greater in conidia germinated with glutamate than in those germinated with ammonia. This result is identical to the results for methylamine transport by conidia germinated with glutamate or ammonia (Cook \& Anthony, 1978). 


\section{Methylamine transport activity in methylamine-resistant mutants of A. nidulans}

Mutants at the meaA and meaB loci confer resistance to high concentrations of methylamine and Pateman et al. (1974) have proposed that resistance may be due to loss of ability to transport this substrate. Although the transport system described in the present work is probably the same as that briefly characterized in mycelium (stage of growth unstated) by Pateman et al. (1974) in their study of methylamine resistance, our results (Table 4) clearly demonstrate that the high affinity ammonia and methylamine transport system is not markedly altered in the methylamine-resistant mutants. Our results do not rule out the possibility (Arst \& Page, 1973) that some mea mutants may be altered in the ability to transport rapidly high concentrations of ammonia ('bulk' transport) when this is a major source of nitrogen in the growth medium

\section{DISCUSSION}

The results presented in this paper demonstrate that ammonia and methylamine are actively transported by a single transport system in germinated conidia of $A$. nidulans. This system has a greater affinity for ammonia than for methylamine or ethylamine and is similar to that in $P$. chrysogenum (Hackette et al., 1970); both are repressed by growth with ammonia and derepressed by nitrogen starvation (Anthony \& Cook, 1973; Cook, 1976; Cook \& Anthony, 1978; Hackette et al., 1970). The function of these two systems is probably not the 'bulk' transport of ammonia as a major nitrogen source; they probably act as 'scavengers' of low concentrations of ammonia during periods of nitrogen deficiency or when an alternative major nitrogen source is available.

The results in Table 4 demonstrate that the high affinity ammonia transport system described in the present work is repressed (in wild type and methylamine-resistant mutants) by ammonia or a metabolite of ammonia. The regulation of this system is further described in the following paper (Cook \& Anthony, 1978).

We thank the SRC and Rank Hovis McDougall (Research) Ltd for the award of a CASE studentship for R. J. Cook.

\section{REFERENCES}

ANTHONY, C. \& CoOK, R. J. (1973). Regulation of methylamine transport during germination of Aspergillus nidulans. Journal of General Microbiology 77, vii.

Arst, H. N. \& Cove, D. J. (1969). Methylamine resistance in Aspergillus nidulans. Journal of Bacteriology 98, 1284-1293.

ARST, H. N. \& Cove, D. J. (1973). Nitrogen metabolite repression in Aspergillus nidulans. Molecular and General Genetics 126, 111-141.

ARst, H. N. \& PAGE, M. M. (1973). Mutants of Aspergillus nidulans altered in the transport of methylammonium and ammonium. Molecular and General Genetics 121, 239-245.

Cook, R. J. (1976). Methylamine, ammonia and acidic amino acid transport in Aspergillus nidulans. Ph.D. thesis, University of Southampton.

CoOK, R. J. \& ANTHONY, C. (1973). Active transport of methylamine and ammonia in germinating conidia of Aspergillus nidulans. Journal of General Microbiology 77, vii.
Cook, R. J. \& ANThony, C. (1978). Regulation by glutamine of ammonia transport in Aspergillus nidulans. Journal of General Microbiology 109, 275-286.

Cooney, D., Davis, R. \& Van Atta, G. (1971). A spectrophotometric method for the simultaneous measurement of L-glutamine and L-asparagine in biological materials. Analytical Biochemistry 40, 312-326.

Hackette, S. L., Skye, G. E., Burton, C. \& Segel, I. H. (1970). Characterization of an ammonium transport system in filamentous fungi with methylammonium $-{ }^{14} \mathrm{C}$ as the substrate. Journal of Biological Chemistry 245, 4241-4250.

Large, P. J., Eady, R. R. \& Murden, D. J. (1969). An enzymic method for the micro-estimation of methylamine, ethylamine and n-propylamine. Analytical Biochemistry 32, 402-407.

Pall, M. L. (1970). Amino acid transport in Neurospora crassa. II. Properties of a basic amino acid transport system. Biochimica et biophysica acta 203, 473-483. 
Pateman, J. A., Kinghorn, J. R., Dunn, E. \& FORBES, E. (1973). Ammonium regulation in Aspergillus nidulans. Journal of Bacteriology 114, 943-950.

Pateman, J. A., Dunn, E., Kinghorn, J. R. \& Forbes, E. C. (1974). The transport of ammonium and methylammonium in wild-type and mutant cells of Aspergillus nidulans. Molecular and General Genetics 133, 225-236.

Pontecorvo, G., Roper, J. A., Hemmons, L. M., MacDonald, K. D. \& Bufton, A. W. J. (1953). The genetics of Aspergillus nidulans. Advances in Genetics 5, 141-238.

Ressler, C. \& KogA, T. (1971). $\alpha$-Cyanoamino acids and related nitriles as inhibitors of glutamate decarboxylase. Biochimica et biophysica acta 242, 473-483.
Robinson, J. H. (1973). Amino acid transport in Aspergillus nidulans. Ph.D. thesis, University of Southampton.

Robinson, J. H., Anthony, C. \& Drabble, W. T. $(1973 a)$. The acidic amino-acid permease of Aspergillus nidulans. Journal of General Microbiology 79, 53-63.

Robinson, J. H., Anthony, C. \& Drabble, W. T. $(1973 b)$. Regulation of the acidic amino-acid permease of Aspergillus nidulans. Journal of General Microbiology 79, 65-80.

Robinson, J. H., Anthony, C. \& Drabble, W. T. (1974). The utilization of nitrogen sources by Aspergillus clavatus. Journal of General Microbiology 85, 23-28.

SUzUKI, T. (1973). Metabolism of methylamine in the tea plant (Thea sinensis L.) Biochemical Journal 132, 753-763. 